\title{
Papillary tumor of the pineal region
}

Figure 1 MRI showing a cystic pineal region mass causing supratentorial obstructive hydrocephalus (A) and MRI performed after surgical resection (B)
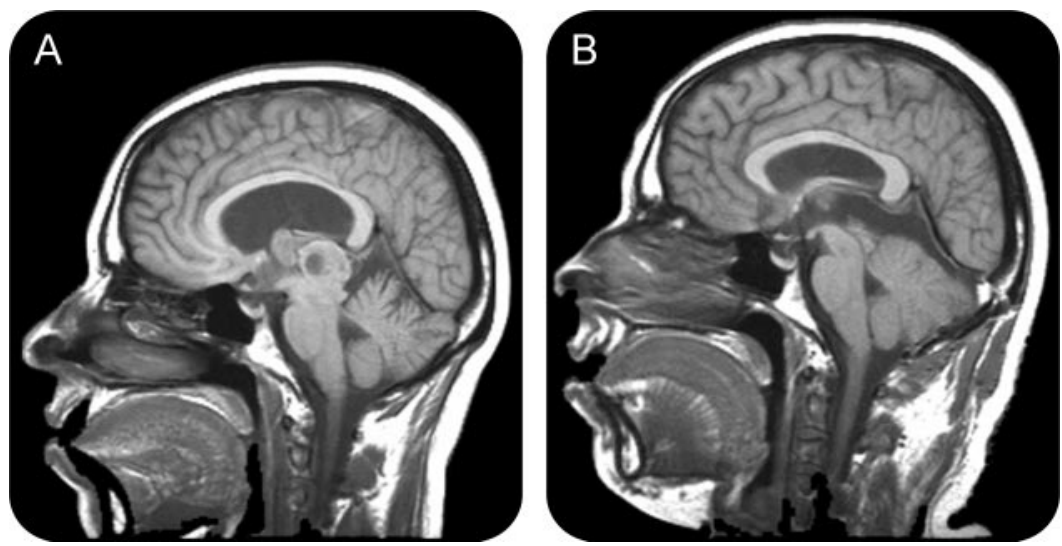

A 29-year-old woman presented with headache, vomiting, and progressive diplopia. MRI showed a cystic pineal tumor and supratentorial obstructive hydrocephalus. The patient underwent endoscopic ventriculostomy for hydrocephalus treatment. Afterwards, microsurgical resection of the tumor was performed (figure 1). Pathologic examination showed a lesion with papillary architecture (figure 2).

Tumors of the CNS demonstrating papillary fea-

Figure 2 Pathologic examination showing an epithelial-appearing tumor with papillary features

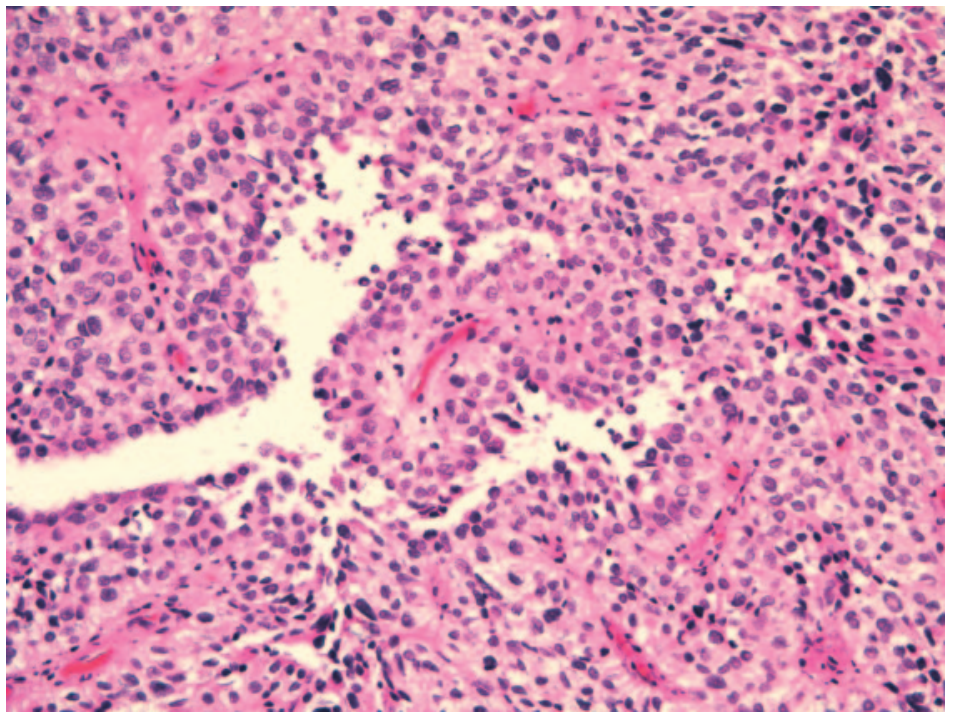

tures are rare. The biologic behaviour, natural course, and appropriate therapy for these recently described entities is not clear. The high risk of local recurrence makes radiotherapy necessary to achieve optimal treatment. ${ }^{1,2}$ Papillary pineal tumors should be included in the differential diagnosis of symptomatic pineal region masses.

Alejandro F. Coello, MD, Alberto Torres, $M D$,

Juan Jose Acebes, PhD, Susana Boluda, MD, Barcelona, Spain

Disclosure: The authors report no disclosures.

Address correspondence and reprint requests to Dr. Alejandro F. Coello, Hospital Universitario de Bellvitge, Comerç no. 10 Bis 2, 08003,Barcelona,Spain; jandrocoello@gmail.com

1. Jouvet A, Fauchon F, Liberski P, et al. Papillary tumor of the pineal region. Am J Surg Pathol 2003;27:505-512.

2. Fevre Montange M, Hasselblatt M, Figarella-Branger D, et al. Prognosis and histopathologic features in papillary tumors of the pineal region: a retrospect of 31 cases. J Neuropathol Exp Neurol 2006;65:1004-1011. 


\section{Neurology}

\section{Papillary tumor of the pineal region}

Alejandro F. Coello, Alberto Torres, Juan Jose Acebes, et al. Neurology 2009;73;486

DOI 10.1212/WNL.0b013e3181b16637

\section{This information is current as of August 10, 2009}

\section{Updated Information \&} Services

References

Subspecialty Collections

Permissions \& Licensing

Reprints including high resolution figures, can be found at: http://n.neurology.org/content/73/6/486.full

This article cites 2 articles, 0 of which you can access for free at: http://n.neurology.org/content/73/6/486.full\#ref-list-1

This article, along with others on similar topics, appears in the following collection(s):

Diplopia (double vision)

http://n.neurology.org/cgi/collection/diplopia_double_vision Primary brain tumor

http://n.neurology.org/cgi/collection/primary_brain_tumor

Information about reproducing this article in parts (figures,tables) or in its entirety can be found online at:

http://www.neurology.org/about/about_the_journal\#permissions

Information about ordering reprints can be found online:

http://n.neurology.org/subscribers/advertise

Neurology ${ }^{\circledR}$ is the official journal of the American Academy of Neurology. Published continuously since 1951, it is now a weekly with 48 issues per year. Copyright . All rights reserved. Print ISSN: 0028-3878. Online ISSN: 1526-632X.

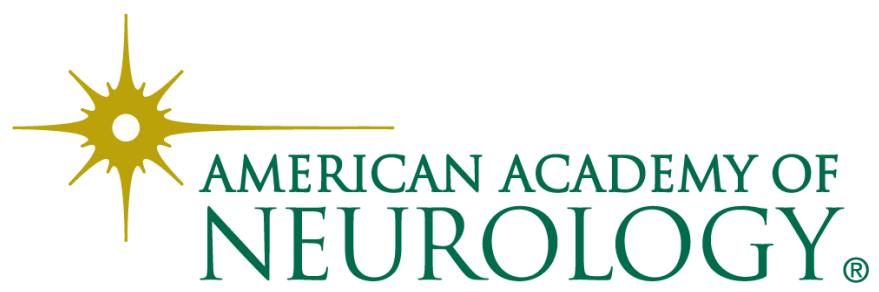

